\title{
An analysis of language and speech disorders in preschool children in Turkey: The case of Beypazar1
}

\author{
Türkiye'de okul öncesi çocuklarda dil ve konuşma bozukluklarının \\ analizi: Beypazarı örneklemi
}

\author{
Ayşe Sanem Şahl1 ${ }^{1}$, Fatih Mehmet Şahin ${ }^{2}$, Erol Belgin ${ }^{3}$
}

\section{Article History \\ Received : 11 June 2018 \\ Revised : 29 June 2018 \\ Accepted : 01 July 2018 \\ Online : 04 July 2018 \\ Article Type \\ Original Article}

\begin{abstract}
Makale Geçmişi
Geliş : 11 Haziran 2018

Düzeltme : 29 Haziran 2018

Kabul : 01 Temmuz 2018

Çevrimiçi : 04 Temmuz 2018
\end{abstract}

Makale Türü

Özgün Makale

\begin{abstract}
The children with early language and speech delay have the risk to face with learning disabilities as well as psychological and behavioral adjustment problems in the preschool period. The aim of this study to analyse the language and speech disoders in the children aged between 3 and 6 years who attend kindergarden. 503 children who attend the kindergarden were determined in Beypazar1. However, 101 children were out of study for various reasons (N:402). The implementation of the study consists of two stages. In the first stage, the language and speech development of the children was determined with the Language and Speech Screening Form. The Turkish Preschool Language Scale-5 (TPLS-5) test was administered to the risky children in the second stage. The data obtained from the first stage of study, 23 of 402 children were considered to have problems in language and speech development. The TPLS -5 language test was administered to 22 out of 23 children. A moderate $(0.30<|r=0.49|<0.70)$, positive $(r>0)$ and a significant correlation $(\mathrm{p}<0.05)$ was found between their chronological age and their receptive language age. A high level $(0.70<|r=0,88|)$, positive $(r>0)$ and significant correlation $(p<0.01)$ was found between the chronological and expressive language of the children. Language-speech screenings in preschool children are useful for identifying possible or existing language-speech problems and for intervention in the shortest possible time. The language and speech disorders seen in children cause some negative effects on the families and affect society considerably in the long term. For this reason, it is quite important to follow the language and speech development of children closely in the preschool period.
\end{abstract}

Keywords: Children; preschool; language; speech; language and speech disorder

Öz: Dil ve konuşma gecikmesi olan çocukların, okul öncesi dönemde hem öğrenme güçlüğü hem de psikolojik ve davranışsal uyum sorunları ile karşılaşma riski vardır. Bu çalışmanın amacı, anaokuluna devam eden 3-6 yaş arasındaki çocuklarda dil ve konuşma bozuklarını analiz etmektir. Beypazarı'nda anaokuluna devam eden toplam 503 çocuk belirlenmiştir. Ancak, 101 çocuk çeşitli nedenlerle çalışma dışı kalmıştır (N: 402). Çalışmanın uygulanması iki aşamadan oluşmaktadır. İlk aşamada çocukların dil ve konuşma gelişimi Dil ve Konuşma Formu ile sorgulanmıştır. İkinci aşamada riskli çocuklara Türkçe Okul Öncesi Dil Ölçeği-5 (TPLS-5) testi uygulanmıştır Çalışmanın ilk aşamasından elde edilen verilerden 402 çocuktan 23'ünün dil ve konuşma gelişiminde problem olduğu düşünülmüştür. TPLS-5 dil testi 23 çocuğun 22 'sine uygulandı. Çocukların kronolojik yaşları ve alıcı dil yaşları arasında orta $(0.30<\mid r=0.49$ $\mid<0.70)$, pozitif $(r>0)$ ve anlamlı bir korelasyon $(\mathrm{p}<0.5)$ bulunmuştur. Çocukların kronolojik yaşları ile ifade edici dil yaşları arasında ise yüksek düzeyde $(0.70<|r=0.88|)$, pozitif $(r>0)$ ve anlamlı bir korelasyon ( $\mathrm{p}<0.01$ ) elde edilmiştir. Okul öncesi çocuklarda dil-konuşma taramaları olası veya mevcut dil-konuşma problemlerinin belirlenmesi ve mümkün olan en kısa sürede müdahale edilmesi için faydalıdır. Çocuklarda görülen dil ve konuşma bozukluğu, aileler üzerinde bir takım olumsuz etkiler yaratmakta ve uzun vadede toplumu önemli düzeyde etkilemektedir. Bu nedenle, çocukların okul öncesi dönemde dil ve konuşma gelişimlerini yakından takip etmek oldukça önemlidir.

Anahtar Kelimeler: Çocuk; okul öncesi; dil; konuşma; dil ve konuşma bozukluğu

DOI: $\underline{10.24130 / \text { eccd-jecs. } 196720182386}$

Corresponding Author: Ayşe Sanem Şahlı

${ }^{1}$ Hacettepe University, Vocational School of Health Services, Hearing and Speech Training Center, ssahli@ hacettepe.edu.tr, ORCID: https://orcid.org/0000-0001-5050-8994

${ }^{2}$ Ondokuz Mayıs University, Vocational School of Health Services, fmsodyo@ hotmail.com, ORCID: https://orcid.org/0000-0001-92494201

${ }^{3}$ Istanbul Medipol University, Faculty of Health Sciences, Department of Audiology, erol.belgin@ gmail.com, ORCID:

https://orcid.org/0000-0001-7252-3378 


\section{INTRODUCTION}

A language an/or speech deficiency implies that the child is developing speech or language in the correct sequence but at a slower rate than expected, while a language or speech disorder suggests that the child's language or speech ability is qualitatively different from typical development (AHRQ, 2015). The delay and/or deficiency in development of verbal communication is one of the most well-known sign for children with language-speech disorder. The level of language development of a child can be the best sign of a developmental problem (Green and Qualls,2010). The National Information Center for Children and Youth with Disabilities (NICHCY) reported that one out of every ten people in USA has a communication problem and more than one million students attending schools have one type of language and speech problem (NICHCY, 2017).

The delay in speech and language is one of the most common developmental disorders in early childhood period with a prevalence ratio of $6 \%$. About $60 \%$ of language delay among the children aged between 2-3 is solved when children grow. However, serious language delays may cause harmfull effects later if these problems are not treated in the early period (Green and Qualls, 2010; ASHA, 2018). Approximately 2.6 percent of children ages 3 to 5 years were served under IDEA in 2007 for language and speech defiencies in the United States (U.S. Department of Education, 2009). Some related research (Horwitz et al, 2003; Klee et al,1998; Reilly et al, 2007; Rescorla, 1989; Zubrick, Taylor, Rice and Slegers, 2007) shows that 10-19\% of children younger than age 3 are affected by language delay without any solid or known reasons. A systematic review conducted by Law et al estimated the prevalence of speech and/or language delays in children ages 2 to 5 years to be between 5 and 12 percent. In children 7 years old and younger in the United Kingdom the median prevalence of receptive language delay/disorder ranged from 2.63\%-3.59\%, expressive language delay/disorder ranged from $2.81 \%-16 \%$, and combined receptive and expressive language delay/disorder ranged from 2.02\%-3.01\% (Law et al, 2000). The prevalence of language impairment in Canadian kindergarten children was $8.04 \%$ overall, $8.37 \%$ for girls, and $8.17 \%$ for boys (Beitchman et al, 1986).

In a population-based study in Utah, the prevalence of language or speech was 63.4 cases per 1,000 children (Pinborough-Zimmerman et al, 2007). The numbers are thought to be higher in some other countries (i.e. China and Africa) in contrast to USA and Canada (CASLPA,2018; ASHA, 2018; Beitchman et al, 1986). The ratio of people who have language and speech 
obstacles among male children population is $0.48 \%$ and this ratio is $0.28 \%$ in female children population (TSI, 2002).

Early intervention for language and speech problems helps the child in reading, writing, fulfilling the tasks given and being more successful in interpersonal relationships (ASHA, 2018; Sylvestr, 2012).

Preschool children with language disorder (aged between 3 and 6) may have problems related to Receptive Language (RL)/Auditory Perception (AP) and Expressive Language (EL) skills. The children with receptive language deficiency in the preschool period have usually difficulties in understanding the meanings of gestures, following directions, answering questions, describing pictures and objects and turn-taking during conversation. The children with expressive (speech) language disorder, on the other hand, have problems in asking questions, using gestures, making grammatical sentences, learning rhythm and songs, starting and continuing conversations (Reilly et al, 2007; Rescorla, 1989; Zubrick et al, 2007; Tomblin et al,1997; Law et al, 2000). Language and speech tests have an important role in evaluating language and speech development of children. Evaluating the speech development of children is usually done with the information provided from the parents until the age of 2 . After the age of 2, tests are used for evaluations related to language development of children in which children directly answers the questions (Zimmerman et al, 2002; Zimmerman et al, 2011; Sahli and Belgin, 2017). The Turkish Preschool Language Scale-5 (TPLS-5) can be used to evaluate and diagnose children with language and speech deficiency in terms of their receptive and expressive language skills, particularly between the neonatal stage and the age of 2 . Through the TPLS-5, children can benefit from an increased likelihood of early diagnosis and intervention related to language delay. Although there are various language assessment tests in our country (Tedil, Todil, Tifaldi etc.), these tests do not assess the receptive and expressive language skills of children between 0-2 years of age. However, between 0-2 years of age is very important in the detection and intervention of language and speech delays (Brown et al, 2016).

In our study, it is aimed to determine RL/AP and EL development of children who are considered to have language and speech delay with Turkish Preschool Language Scale-5 (TPLS-5) based on the data collected from the screening of the language and speech development of children who are aged from 3 to 6 years and attend a kindergarden in Beypazar1, Turkey. The researchers searched the questions about language and speech development of pre- 
school children living in this region, relation of language skills and chronological age and, the frequency of language and speech delays.

\section{METHOD}

The study is a quantitative descriptive research. This study aim to analyse the language and speech development of the children aged from 3 years to 5 years and 11 months who attend kindergarden. It was carried out following taking the official permission from the Ministry of National Education dated 04.11.2014 and numbered 14588481/605.99/4990420 and the ethics committee approval granted from the Medical and Health Science Research Board dated 27.08.2014 and numbered 14/88. First the number of children who are aged between 3 and 6 years who attend kindergarden of the Ministry of National Education in Beypazarı, Ankara, was determined. The main reason for the selection of the Beypazarı district as a research universe; there has never been a study in this district that assessed the language and speech skills of preschool children. Beypazar1 is also one of the researchers' place of duty, and the researchers have easy access to kindergardens and children there.

In the study, 503 children aged between 3 and 6 years who were attending a kindergarden in Beypazarı, Ankara, participated in the study. Of them 21 did not continue their school for unknown reasons. According to the data obtained from the school records of the remaining 482 children, 4 of them were determined to have at least one disability ( 2 of them were mentally retarted, 1 of them was autism spectrum disorder and 1 of them had hearing impairement) and these children were excluded from the research.

In addition, the parents of 76 of the remaining 478 children rejected to participate in the study for various reasons. As a result the parents of 402 children accepted to participate in the study. The children who are considered as healthy and who have not a diagnosed disease or disability were included in the study. The study was carried out in two stages which are explained as follows:

Stage 1: In this stage, "The Language and Speech Development Screening Form" that was prepared by field specialists, including 17 questions related to general characteristics of children like gender, age and language and speech development was administered to teachers and parents of children. This form was used to identify children who were delayed or suspicious in terms of language and speech development. More specifically, people who were the primary caregivers to children (mother, father, caretaker, grandmother etc.) were asked to fill the 
screening forms. The forms filled by parents were examined by the researchers, and then, the children who were considered to have risk in terms of language and speech development were identified. Parent consent and necessary permissions are obtained and parents are informed of the situation of their child both before and after the test.

Stage 2: In this stage of the study, the Turkish Preschool Language Scale-5 (TPLS-5) was administered to the children who were considered to have risk in terms of language and speech development, and then, their AP/RL and EL ages were identified. The Preschool Language Scale-5 (PLS-5) is a language evaluation test which was developed by Zimmerman, Steiner and Pond in 2011 (Zimmerman et al, 2011). The test was adapted for Turkish children in 2013. Its validity and reliability analyses were carried out by Sahli and Belgin on a sample of 1320 children aged between 0-7 years 11 months (Sahli and Belgin, 2017). The Turkish PLS-5 consists of two standard scales (Auditory Perception/ Receptive Language (AP/RL) ) and Expressive Language (EL) and three additional measurements (The Language Sample Checklist, Articulation Screener Scale, and Home Communication Questionnaire) (Sahli and Belgin, 2017). The Auditory Perception/Receptive Language and Expressive Language standard scales of the TPLS-5 are used in our study. The Auditory Comprehension/Receptive Languge (AC/RL) scale is used to evaluate the child's language comprehension level. The Expressive Communication (EC) scale is used to determine how the child communicates with others.

\section{Statistical analysis}

For the analysis of the data obtained SPSS 20 (IBM Corp. Released 2011. IBM SPSS Statistics For Windows, Version 20.0. Armonk, NY: IBM Corp.) package program was used. The variables, means, standard deviation and median (Maximum-Minimum) percentage and frequency values were calculated. The categorical data was analyzed using the Fisher's exact test, chi square test, McNemar Bowker Test and Pearson Correlation. In the cases where the frequencies were lower than 20\%, the "Monte Carlo Simulation Method" was used in order to include these frequencies into the analysis. The level of significance is set at $p<0,05$ and $p<0,01$.

\section{RESULTS}

503 children aged between 3 and 6 years who were attending a kindergarden were determined in Beypazarı, Ankara. However, the parents of 402 children accepted to participate in the study. The distribution of participation in the study is given in Table 1. 
Table 1. The distribution of children according to their participation

\begin{tabular}{lcc}
\hline \multicolumn{1}{c}{ Age groups of children } & f & \% \\
\hline 3:0-3:5 years & 2 & 0.5 \\
\hline $3: 6-3: 11$ years & 13 & 3.2 \\
\hline 4:0-4:5 years & 38 & 9.5 \\
\hline 4:6-4:11 years & 49 & 12.2 \\
\hline $5: 0-5: 5$ years & 117 & 29.1 \\
\hline $5: 6-5: 11$ years & 183 & 45.5 \\
\hline Total & 402 & 100 \\
\hline
\end{tabular}

In terms of gender 196 of 402 children (48.8\%) were girls and 206 of them (52.2\%) were boys. The mean age of the children participated in the study was $62,84 \pm 6,93$ months (Min.: 39 months, Max.: 71 months, S.D:6.77247). The data showing the age of the participants is given in Table 2. Table 2 indicates that $0,5 \%$ of the children $(\mathrm{N}: 2)$ are between the ages of 3 years-3 years and 5 months; $3,2 \%$ of them $(\mathrm{N}: 13)$ are between the ages of 3 years and 6 months and 3 years 11 months; $9,5 \%$ of them $(\mathrm{N}: 38)$ are between the ages of 4 years -4 years and 5 months; $12,2 \%$ of them $(\mathrm{N}: 49)$ are between the ages of 4 years and 6 months - 4 years and 11 months; $29,1 \%$ of them $(\mathrm{N}: 117)$ are between the ages of 5 years-5 years and 5 months and $45,5 \%$ of them $(\mathrm{N}: 183)$ are between the ages of 5 years- 6 months and 5 years- 11 months.

Table 2. The distribution of children according to ages groups

\begin{tabular}{lcc}
\hline Children's participation in the research & f & \% \\
\hline Accepted to participate & 402 & 79.9 \\
\hline Rejected to participate & 76 & 15.1 \\
\hline Child did not continue kindergarden for various reasons & 21 & 4.2 \\
\hline Child was excluded from the research because of an extra developmental problem & 4 & 0.8 \\
\hline Total & 503 & 100 \\
\hline
\end{tabular}

The data obtained from the first stage of study, 23 of 402 children were considered to have problems in language and speech development. The PLS-5 language test was administered to 22 out of 23 children. The other child could not be reached because he/she dropped out of school. Of them 7 (31.8\%), who were considered to have language and speech problem are boys and 15 (68.2) of them are girls. The average chronological age of the children is determined as 59.4 months (min.: 41 , maks.:69, S.D.: \pm 7.43 ).

The comparison between the RL/AP age and chronological ages of the children with and without language and speech disorder indicated that the RL age of 77,3\% of the children falls behind the limit and that the RL age development of $9,1 \%$ of the children is normal, the RL age of $13,6 \%$ of the children is in advance of their chronological ages $\left(X^{2}=19,182 ; p<0,01\right)$. Table 
3 shows the comparison of the RL and chronological ages of the children who are thought to have language and speech problem.

Table 3. The comparison of the children according to their receptive language ages and chronological ages

\begin{tabular}{|c|c|c|c|c|}
\hline $\begin{array}{l}\text { Receptive language age according to } \\
\text { chronological ages }\end{array}$ & $\mathbf{f}$ & $\%$ & $\mathbf{X}^{2}$ & $\mathbf{p}$ \\
\hline Receptive language is more developed than chronological age & 17 & 77.3 & \multirow{4}{*}{19.182} & \multirow{4}{*}{0.000} \\
\hline Normal & 2 & 9.1 & & \\
\hline $\begin{array}{l}\text { Receptive language is underdeveloped in comparison with } \\
\text { chronological age }\end{array}$ & 3 & 13.6 & & \\
\hline Total & 22 & 100 & & \\
\hline
\end{tabular}

One of the findings of the study suggests that there is a moderate $(0,30<|\mathrm{r}=0,49|<0,70)$, positive $(r>0)$ and significant correlation $(\mathrm{p}<0,05)$ between the chronological and EL ages of the children who are thought to have language and speech disorder. However, a high level $(0,70<|r=0,88|)$, positive $(r>0)$ and a significant correlation $(p<0,01)$ is found between the chronological and EL ages of the children (N:22).

Table 4 indicates the comparison of the chronological ages and the EL ages of the children who are thought to have language and speech disorder. It is found that the EL is more developed than chronological age in $86,4 \%$ of the children and normal in $13,6 \%$ of the children $\left(X^{2}=11,636 ; p<0,01\right)$.

Table 4. The comparison of the children according to their expressive language ages and chronological ages

\begin{tabular}{lllll}
\hline $\begin{array}{l}\text { Expressive language age according to chronological } \\
\text { age }\end{array}$ & $\mathbf{f}$ & $\mathbf{\%}$ & \multicolumn{1}{c}{$\mathbf{X}^{\mathbf{2}}$} & $\mathbf{p}$ \\
\hline $\begin{array}{l}\text { Expressive language age is more developed than } \\
\text { chronological age }\end{array}$ & 19 & 86.4 & & \\
\cline { 1 - 3 } $\begin{array}{l}\text { Normal } \\
\text { Expressive language age is underdeveloped in }\end{array}$ & 3 & 13.6 & 0.001 \\
$\begin{array}{l}\text { comparison with chronological age } \\
\text { Total }\end{array}$ & - & - & \\
\hline
\end{tabular}

\section{DISCUSSION}

In our study, the data were collected about age, gender, communication, language and speech skills regarding the participants, who were the children aged from 3 to 6 years and attend kindergarden. As stated earlier in the current study 503 children were sampled. The mothers and/or fathers of 402 agreed to participate in the study.

In addition, 23 of the children who filled forms with their parents and other family members were evaluated to see whether or not they had any problem related to their language and speech 
development. One of these children could not be reached, prior knowledge form was filled with the family and the teachers and Turkish Preschool Language Test-5 (TPLS-5) was carried out for 22 children. In our study, 7 (31.8\%) of the children who are considered to have language and speech disorder are girls and $15(68.2 \%)$ of them are boys. This shows that boys may have language and speech disorders more frequently than girls. In the study of Campbell et. al., the ratio of the boys who have speech delay are found to be at statistically significant level (Odds Ratio:219) (Campbell et al, 2003).

The studies related to PLS-5 are very limited in the literature. One of the factors seems to be that the scale was newly developed. One of the studies which used the PLS-5 was about the children with autism spectrum disorder and the other one was carried out on a sample of the stuttering children. Carter et al (2015)'s study, “The Effects of Educational Kinesiology Tasks on Stuttering Frequency of a Preschool Child Who Stutters", the children's comprehensive RL and EL age evaluation was carried out using the PLS-5. The study concluded that their comprehensive RL and EL age was in the normal limits (Carter et al, 2015). Based on such findings it was suggested that both the PLS-5 and its earlier versions can be used both for the follow-up of the preschool children's language and speech development and for determining their RL and EL ages. PLS-5 which was developed to evaluate the RL and EL skills of the children aged between 0 and 8 was adapted into Turkish culture and normalised. It is one of the useful language tests to screen the children (Sahli and Belgin, 2017). In the current study the children who attend the kindergarden were screened in terms of their language and speech development. Therefore, the our study provides an opportunity for the parents, teachers specialists and educators to be informed about these children. Some researches indicate that it is important for the teachers to be directed to the studies regarding the speech and language development and communication, to be provided with responsibilities in courses and social projects. Levels of knowledge for educators to develop language development and communication skills are important for language development of children with special educational needs (Akmese and Kayhan, 2016). Based on the findings of the study it can be suggested that consultancy service was provided for the parents of the children who have language and speech disorder. Also, the children were directed to the related institutes for proper intervention and rehabilitation.

The related studies show that language delay as negative effects on school success, and may cause social, emotional and behavioral problems among children (Schuele, 2004; Moeller, 2007; Sahli, 2017) The children who have language and speech disorders can may have long 
term problems that are also observed during the adolescence period. Therefore, it is quite important that the language and speech development of children should be closely followed.

\section{REFERENCES}

Agency for Healthcare Research and Quality (AHRQ). (2015). Screening for Speech and Language Delays and Disorders in Children Age 5 Years or Younger: A Systematic Review for the U.S. Preventive Services Task Force, Evidence Synthesis, Number 120,AHRQ Publication.

Akmese, P. \& Kayhan, N. (2016). An examination of the special education teacher training programs in Turkey and European Union member countries in terms of language programs and communication education, Cypriot Journal of Educational Sciences, 11(4), 185-194.

ASHA (American Speech-Language-Hearing Assosiation). (2018). What is language, what is speech? Retrived from: http://www.asha.org/public/speech/development/language_speech/, date of access: 16 January 2018.

ASHA [American Speech-Language-Hearing Association] (2018). Spoken language disordersincidence and prevalence. Retrived from: https://www.asha.org/PRPSpecificTopic. aspx?folderid=8589935327\&section=Inciden ce_and_Prevalence, date of access: 28 June 2018.

Beitchman, J.H., Nair, R., Clegg, M \& Patel, P.G. (1986). Prevalence of speech and language disorders in 5-year-old Kindergarten children in the Ottawa-Carleton region, J. Speech Hear. Disord, 51, 98-110.

Brown, C. M., Beck, A. F., Steuerwald, W., Alexander, E., Samaan, Z. M., Kahn, R. S., \& Mansour, M. (2016). Narrowing care gaps for early language delay: a quality improvement study. Clinical pediatrics, 55(2), 137-144.

Campbell, T., Dollaghan, C., Rockette, H\& Paradise, J.L., Feldman, H.M. (2003). Risk factors for speech delay of unknown origin in 3-year-old children. Child development, 74(2), 346-357.

Canadian Association of Speech-Language Pathologists and Audiologists (CASLPA). (2018). Speech and language disorder prevalence. Retrived from: https://www.sac-oac.ca/, date of access: 15 January 2018.

Carter, M.D., Tatum, M \& Gorham-Rowan, M. (2015). The effects of educational kinesiology tasks on stuttering frequency of a pre-school child who stutters. The Open Rehabilitation Journal 8, 9-16.

Green, SL \& Qualls, C.D. (2010). Educating children with speech and language disorders, Elsevier. 
Horwitz, S.M., Irwin, J.R., Briggs-Gowan, M.J., BossonHeenan, J.M., Mendoza, J \&Carter, A.S.(2003). Language delay in a community cohort of young children. Journal of American Academy of Child and Adolescent Psychiatry, (42), 932-40.

Klee, T., Carson, D.K., Gavin, W.J., Hall, L., Kent, A \& Reece, S. (1998). Concurrent and predictive validity of an early language screening program. Journal of Speech, Language, and Hearing Research, 41(3), 627-41.

Law, J., Boyle, J., Harris, F., Harkness, A \& Nye, C. (2000). Prevalence and natural history of primary speech and language delay: findings from a systematic review of the literature, International Journal of Language and Communication Disorders, 35(2), $165-88$.

Moeller, M. P. (2007). Current state of knowledge: psychosocial development in children with hearing impairment. Ear and hearing, 28(6), 729-739.

NICHCY [National Information Center for Children and Youth with Disabilities] (2017). Categories of disability under idea, national dissemination center for children with disabilities,Retrivedfrom:https://www.parentcenterhub.org/wpcontent/uploads/repo_it ems/gr3.pdf, date of access: 27 June December 2018.

Pinborough-Zimmerman, J., Satterfield, R., Miller, J., Bilder, D., Hossain, S., \& McMahon, W. (2007). Communication disorders: Prevalence and comorbid intellectual disability, autism, and emotional/behavioral disorders. American Journal of Speech-Language Pathology, 16(4), 359-367.

Reilly, S., Wake, M., Bavin, E..L, Prior, M., Williams, J \& Bretherton Ukoumunne, O.C. (2007). Predicting language at 2 years of age: a prospective community study. Pediatrics, 120 (6),1441-1449.

Rescorla, L. (1989). The language development survey: a screening tool for delayed in toddlers. Journal of Speech and Hearing Disorders, (54), 587-99.

Sahli, A. S., \& Belgin, E. (2017). Adaptation, validity, and reliability of the Preschool Language Scale-Fifth Edition (PLS-5) in the Turkish context: The Turkish Preschool Language Scale-5 (TPLS-5). International journal of pediatric otorhinolaryngology, 98, 143149 .

Sahli, A.S. (2017). Hearing loss in babies and children and its effects, In: Basic Audiology II, (Erol Belgin\& A. Sanem Sahli, Ed.), (pp. 391-405). Ankara: Guneş Tıp Publishing,

Schuele, C. M. (2004). The impact of developmental speech and language impairments on the acquisition of literacy skills. Mental Retardation And Developmental Disabilities Research Reviews, 10(3), 176-183.

Sylvestre, A., Desmarais, C., Meyer, F., Bairati, I., Rouleau, N., \& Mérette, C. (2012). Factors associated with expressive and receptive language in French-speaking toddlers clinically diagnosed with language delay. Infants \& Young Children, 25(2), 158-171. 
Tomblin, J. B., Records, N. L., Buckwalter, P., Zhang, X., Smith, E., \& O’Brien, M. (1997). Prevalence of specific language impairment in kindergarten children. Journal of Speech, Language, and Hearing Research, 40(6), 1245-1260.

TSI [Turkish Statistical Institute]. (2002). Turkey disability survey, the proportion of disabled population by type of disability. TurkStat Webpages (Statistics by Theme) Retrived from: www.turkstat.gov.tr.

U.S. Department of Education. (2009). Office of Special Education and Rehabilitative Services, Office of Special Education Programs. 31st Annual Report to Congress on the Implementation of the Individuals with Disabilities Education Act. Washington, DC.

Zimmerman, I.L., Steiner, V.G \& Pond, R.E.(2011). Preschool Language Scale-fifth edition (PLS-5), San Antonio:Pearson.

Zimmerman, I.L., Steiner, V.G\& Pond, R.E. (2002). Preschool Language Scale-fourth edition, San Antonio:The Psychological Corporation,

Zubrick, S. R., Taylor, C. L., Rice, M. L., \& Slegers, D. W. (2007). Late language emergence at 24 months: An epidemiological study of prevalence, predictors, and covariates. Journal of Speech, Language, and Hearing Research, 50(6), 1562-1592. 